\title{
Chemical composition, phytotoxic potential, biological activities and antioxidant properties of Myrcia hatschbachii D. Legrand essential oil
}

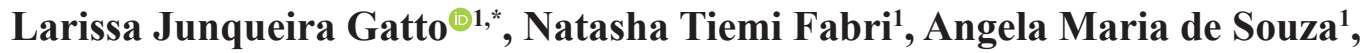 \\ Natasha Stopinski Triaquim da Fonseca ${ }^{1}$, Alethéia dos Santos Furusho ${ }^{1}$, Obdulio Gomes Miguel ${ }^{1}$, \\ Josiane de Fatima Gaspari Dias', Sandra Maria Warumby Zanin1, Marilis Dallarmi Miguel ${ }^{1}$
}

${ }^{1}$ Department of Pharmacy, Federal University of Parana, Curitiba, Parana, Brazil

\begin{abstract}
Myrcia hatschbachii D. Legrand (Myrtaceae) is a native and endemic species from Brazil. This study investigated the essential oil composition, phytotoxic potential, in vitro toxicity, antioxidant properties and antibacterial activity of species. Chromatographic analysis of essential oil identified trans-calamanene, (E)-caryophyllene and spathulenol as major components. Antioxidant capacity was determined by the $\mathrm{DPPH} \bullet$ scavenging method and phosphomolybdenum complex formation assay. Antibacterial activity was evaluated using the Minimal Inhibitory Concentration test, demonstrating that the essential oil was active toward Enterococcus faecalis and Staphylococcus aureus. Phytotoxic activity of essential oil was analyzed by testing interference on germination and growth of Lactuca sativa, demonstrating significant inhibition of the hypocotyls and radicles of seeds. Preliminary toxicity studies were determined using Artemia salina, resulting in an $\mathrm{LC}_{50}$ of $409.92 \mu \mathrm{g} / \mathrm{mL}$, and through hemolytic activity. The results of the phytotoxic activity point to a possible application for Myrcia hatschbachii in the development of natural herbicides and the in vitro toxicity assays suggests the performance of antitumoral activity tests, having in mind the prospection of antineoplastic drugs.
\end{abstract}

Keywords: Essential oil. Phytotoxic. Antioxidant. Antibacterial. Hemolysis. Artemia salina.

\section{INTRODUCTION}

Plants are important sources of biologically active substances and have become industrial models for the development of new drugs, whether of natural origin or chemical synthesis planned from natural products (Barreiro, Bolzani, 2009). Interest in aromatic species has grown steadily in recent years, particularly with regard to essential oils, which are of great economic interest and are widely described in the literature (Stefanello et al., 2011). Essential oils may be alternatives for synthetic compounds used in pharmaceutical formulations, chemistry applications, foods, cosmetics, agricultural implements and cleaning materials.

Myrtaceae is one of the largest families of angiosperms and comprises approximately 140 genus and 5500 species, located on continents in the southern

\footnotetext{
*Correspondence: L. J. Gatto. Universidade Federal do Paraná (UFPR), Avenida Mayor Lothario Meisser, 632, Curitiba, PR, Brazil. Phone: +55 41 3360-4070. E-mail: lari.gatto@gmail.com
}

hemisphere (Retamales, Scharaschkin, 2015). The species of the family are abundant in Brazil and present an economic importance, as a source of fruits, spices, timber and paper, and utilization as a therapeutic agent, folk remedy, and as an ornamental plant (Moresco et al., 2014).

The Myrcia genus comprises a large portion of economically useful species of the family. Myrcia species are important sources of essential oils and are widely used in folk medicine, primarily for treatment of diabetes, an illness of worldwide importance. Essential oils are produced in leaves, stems, flowers and fruits, and are comprised mainly of sesquiterpenes (Cascaes et al., 2015).

Several studies have highlighted the main properties of essential oils derived from the Myrcia species. Myrcia ovata leaf essential oil (EO) extracts exert anti-inflammatory (Santos et al., 2014) and larvicidal (Lima et al., 2011) activities. EO extracts of Myrcia fallax flowers (Alarcón et al., 2009), Myrcia myrtillifolia leaves (Cerqueira et al., 2007), and Myrcia splendens stems (Jiménez et al., 2012) exhibit antimicrobial 
activities. EO of Myrcia tomentosa, Myrcia bella, and Myrcia lingua leaves have antioxidant properties (Takao, Imatomi, Gualtieri, 2015). EO of Myrcia laruotteana fruits have antiproliferative properties (Stefanello et al., 2011).

The species Myrcia hatschbachii D. Legrand is native and endemic to Brazil, with confirmed occurrences in the Southern Region (Sobral et al., 2015). The aim of this study was to investigate the composition of essential oil, and evaluate, for the first time, its phytotoxic potential, toxicity aspects using in vitro models, antioxidant properties and antibacterial activity. This species can be cultivated for extraction of essential oil and may have unidentified beneficial properties.

\section{MATERIAL AND METHODS}

\section{Plant material}

Leaves of Myrcia hatschbachii D. Legrand were collected at the Federal University of Parana, Curitiba, Brazil (25 26' S, 49 $14^{\prime} \mathrm{W}$ ) in autumn (April). Species identification was performed by comparison with the specimen held at the herbarium of the Municipal Botanical Museum of Curitiba, under registry number 72379, by the curator José Tadeu Weidlich Motta.

\section{Essential oil extraction}

Plant material was dried at room temperature for 30 days, and $600 \mathrm{~g}$ of leaves were extracted using hydrodistillation by water vapor drag for 6 hours using Clevenger apparatus. EO yield was $0.17 \%$.

\section{Analysis of chemical composition of essential oil}

Identification of EO components was performed using a gas chromatograph coupled to a mass spectrometer (Shidmazu ${ }^{\circledR}$ CG-EM QP2010 Plus), equipped with a capillary column (RTX-5MS; $30 \mathrm{~m} \times 0.25 \mathrm{~mm} \times 0.25 \mu \mathrm{m}$ ). The instrument was operated in split mode with the injector set at $250{ }^{\circ} \mathrm{C}$. The interphase and ion source were maintained at $250^{\circ} \mathrm{C}$. Scan data were collected across the range of $40-350 \mathrm{~m} / \mathrm{z}$. Helium was used as the carrier gas with a constant flow of $1.02 \mathrm{~mL} /$ minute. Initial column pressure was $59 \mathrm{KPa}$, and the programmed temperature rose from $60{ }^{\circ} \mathrm{C}$ to $250{ }^{\circ} \mathrm{C}$ at a rate of $3{ }^{\circ} \mathrm{C} /$ minute. Following data collection, chemical constituents were characterized using the Kovats retention index and comparison to existing literature (Adams, 2007).

\section{Antioxidant activity}

Antioxidant activity was evaluated by the DPPH • radical (2,2-diphenyl-1-picrylhydrazyl) scavenging method (adapted from Mensor et al., 2001) and the phosphomolybdenum complex formation assay (adapted from Prieto, Pineda, Aguilar, 1999). For both methods, EO solutions and standards were prepared (ascorbic acid, rutin and butylated hydroxytoluene [BHT]) at $200 \mu \mathrm{g} / \mathrm{mL}$ in methanol, with the addition of polysorbate 80 . Data were evaluated by ANOVA and statistical differences between results were determined using Tukey's test $(\mathrm{p}<0.05)$.

The following procedure was performed for the $\mathrm{DPPH} \bullet$ radical scavenging method. The reaction was performed in a microplate by mixing $142 \mu \mathrm{L}$ of standard or EO solution with $58 \mu \mathrm{L}$ of methanolic solution of DPPH•. A blank was prepared to account for background color of the sample and methanol was used as a negative control. The reaction was incubated for 30 minutes in the dark at room temperature. Absorbance (Abs) was measured at $540 \mathrm{~nm}$ using a spectrophotometer. Antioxidant activity percentage $(\mathrm{AA} \%)$ of the $\mathrm{EO}$ was calculated as follows: $\mathrm{AA} \%=100-[(($ Abs sample - Abs blank $) \times 100)-$ Abs control].

Phosphomolybdenum complex formation assay was performed as follows. An aqueous reactive solution of sulfuric acid $(0.6 \mathrm{~mol} / \mathrm{L})$, sodium phosphate $(28 \mathrm{mmol} / \mathrm{L})$, and ammonium molybdate $(4 \mathrm{mmol} / \mathrm{L})$ was prepared. In test tubes, $0.3 \mathrm{~mL}$ of standard or EO solution was pipetted, followed by addition of $3 \mathrm{~mL}$ of the aqueous reactive solution. A blank was prepared using the solvents used to prepare samples. The tubes were closed and placed in a water bath at $95^{\circ} \mathrm{C}$ for 90 minutes. Following incubation, samples were allowed to equilibrate to room temperature. Absorbance (Abs) was measured at $690 \mathrm{~nm}$ using a spectrophotometer. Results were expressed as antioxidant activity (AA\%) of the sample compared to ascorbic acid, BHT, and rutin (standards with $100 \%$ antioxidant activity) as follows: AA\% $=[($ Abs sample - Abs blank $) /$ (Abs standard - Abs blank $)] \times 100$.

\section{Lethality against brine shrimp}

Evaluation of toxicity against brine shrimp (Artemia salina) was performed as previously described by Meyer et al. (1982). Artificial saline was prepared by dissolving $14.31 \mathrm{~g}$ of sea salt in $400 \mathrm{~mL}$ of distilled water, with $\mathrm{pH}$ between 8.0 and 10.0. Two hundred milligrams of Artemia salina eggs were added to the saline solution, and the mixture was maintained at $27^{\circ} \mathrm{C}$ to $30^{\circ} \mathrm{C}$, and constantly agitated and illuminated $(20 \mathrm{~W})$ for $48 \mathrm{~h}$ 
to facilitate hatching. EO samples were solubilized in polysorbate 80 and prepared at concentrations of 1000 , $750,500,250,100,50$ and $10 \mu \mathrm{L} / \mathrm{mL}$ in methanol. The positive control, quinidine sulfate, was prepared at the same concentrations. Samples were placed in a laboratory oven at $40^{\circ} \mathrm{C}$ to evaporate solvent. Following evaporation, the samples were resuspended in saline solution and 10 nauplii were incubated. Live and dead nauplii were counted after 24 hours. Data were analyzed using the Probit method, using SPSS version 23.0. The lethal concentration, $\mathrm{LC}_{50}$, and the confidence interval at $95 \%$ were defined.

\section{Hemolytic activity}

In vitro hemolytic activity was performed as previously described by Banerjee et al. (2008). Phosphate buffered (PBS) solution, sample solutions and controls were prepared. Sheep red blood cells solution $(2 \% \mathrm{v} / \mathrm{v})$ was prepared in cold PBS. EO samples were taken from a stock solution, in which the oil was solubilized in $50 \mu \mathrm{L}$ of DMSO (Dimethyl sulfoxide) and 10\% methanol in PBS. Dilutions were made in PBS to obtain 250, 500, 750, and $1000 \mu \mathrm{g} / \mathrm{mL}$ solutions. Triton (1\%) in PBS and clean water were used as positive controls. Phytochemical standards were prepared by diluting saponin to the same concentrations as the samples. The reactions for the sample, phytochemical standard, positive controls, and negative controls (solvent dilution) consisted of $200 \mu \mathrm{L}$ of each respective solution with addition of $200 \mu \mathrm{L}$ of $2 \%$ red blood cells. A blank was prepared to account for the color of the sample by combining $200 \mu \mathrm{L}$ of each sample solution with $200 \mu \mathrm{L}$ of PBS. Samples were incubated at $37^{\circ} \mathrm{C}$ for 3 hours and centrifuged at $3000 \mathrm{rpm}$ for 5 minutes. The supernatant was transferred to a microplate and absorbance was measured at $540 \mathrm{~nm}$ using a spectrophotometer. The percentage of the hemolytic activity was calculated using triton (1\%) and clean water as $100 \%$. Data were analyzed by ANOVA and the statistical difference between results was determined using Tukey's test $(\mathrm{p}<0.05)$.

\section{Antibacterial activity}

Antibacterial activity of EO was evaluated by determining the Minimal Inhibitory Concentration (MIC), using the microdilution method, according to CLSI Clinical and Laboratory Standards Institute (2008). EO were tested against strains of Enterococcus faecalis ATCC 29212, Staphylococcus aureus ATCC 25913, Staphylococcus epidermidis ATCC 12228, Escherichia coli ATCC 25922, Klebsiella pneumoniae ATCC 700603, Pseudomonas aeruginosa ATCC 27853, and Salmonella typhimurium
ATCC 14028. Bacterial suspensions were prepared at $1.0 \times 10^{8} \mathrm{UFC} / \mathrm{mL}$ in saline solution, corresponding to $0.5 \mathrm{on}$ the McFarland scale, and inoculated in microplates $(5 \mu \mathrm{L})$ with a final concentration of $10^{4} \mathrm{UFC} / \mathrm{mL}$. EO samples were prepared in $5 \%$ polysorbate and tested in the range of $1000-3.9 \mu \mathrm{g} / \mathrm{mL}$. Negative controls were prepared by adding $100 \mu \mathrm{L}$ of $5 \%$ polysorbate solution to $100 \mu \mathrm{L}$ of Mueller-Hinton Broth (MHB) and $5 \mu \mathrm{L}$ of the bacterial preparation. The positive control was composed of $100 \mu \mathrm{L}$ of MHB and $5 \mu \mathrm{L}$ of bacterial preparation. The sterility control was prepared by combining $100 \mu \mathrm{L}$ of MHB and $100 \mu \mathrm{L}$ of EO. Microplates were placed in a bacteriological incubator at $35{ }^{\circ} \mathrm{C}$ for 16 to 20 hours. After this period, $20 \mu \mathrm{L}$ of $0.5 \%$ triphenyltetrazolium chloride solution (TTC) was added and the microplates were incubated for 3 hours. MIC results were characterized as follows: good antibacterial activity (up to $100 \mu \mathrm{g} / \mathrm{mL}$ ), moderate activity (between 100-500 $\mu \mathrm{g} / \mathrm{mL}$ ), weak activity (between $500-1000 \mu \mathrm{g} / \mathrm{mL}$ ), and inactive (greater than $1000 \mu \mathrm{g} / \mathrm{mL}$ ) (Ayres et al., 2008; Santos et al., 2008).

\section{Phytotoxic activity}

Phytotoxic activity was evaluated as described by Silva, Overbeck and Soares (2014), in which the influence of EO on germination and growth of Lactuca sativa was evaluated. In gerbox boxes, two paper filters were added at the base and one paper filter was placed on the box cover. A stock solution was prepared by addition of polysorbate 80 to EO. From this stock solution, dilutions were made in distilled water to obtain concentrations of $1 \%, 0.1 \%$, $0.01 \%, 0.001 \%$. Controls consisted of $1 \%$ polysorbate 80 in water. In a laminar flow cabinet, $5 \mathrm{~mL}$ of distilled water was added to the paper filter at the base of the gerbox boxes. The boxes were divided into 4 quadrants, each containing 5 lettuce seeds (Lactuca sativa, variety Grand Rapids). After addition of seeds, $3 \mathrm{~mL}$ of each sample solution was added to the paper filter glued to the box cover. The gerbox boxes were closed and maintained in BOD incubators at $20 \pm 5^{\circ} \mathrm{C}$, for 7 days. During germination, daily readings were collected for 7 days with withdrawal of germinated seeds. Growth verifications were made on the last day through measurement of hypocotyl and radicle growth. Mean differences were determined using the Scott-Knott $(\mathrm{p}<0.05)$ method.

\section{RESULTS AND DISCUSSION}

In the identification of the chemical constituents of EO (Table I) 40 compounds were detected, and among these, 34 terpenes were identified (corresponding to 
TABLE I - Chemical composition of essential oil from Myrcia hatschbachii

\begin{tabular}{|c|c|c|c|c|c|}
\hline RT & $\mathbf{R I}_{\text {cal }}$ & $\mathbf{R I}_{\text {lit }}$ & Compound & Classification & $\%$ \\
\hline 5.600 & 928 & 932 & $\alpha$-Pinene & Monoterpene & 1.46 \\
\hline 6.653 & 967 & 974 & $\beta$-Pinene & Monoterpene & 1.18 \\
\hline 7.017 & 980 & 988 & Myrcene & Monoterpene & 2.48 \\
\hline 8.180 & 1018 & 1025 & $\beta$-Phellandrene & Monoterpene & 1.18 \\
\hline 8.227 & 1019 & 1024 & Limonene & Monoterpene & 0.90 \\
\hline 10.533 & 1083 & 1095 & Linalool & Oxygenated monoterpene & 1.91 \\
\hline 13.543 & 1157 & 1174 & Terpinen-4-ol & Oxygenated monoterpene & 0.76 \\
\hline 14.000 & 1168 & 1186 & $\alpha$-Terpineol & Oxygenated monoterpene & 3.33 \\
\hline 21.517 & 1342 & 1348 & $\alpha$-Cubebene & Sesquiterpene & 1.01 \\
\hline 22.613 & 1368 & 1373 & $\alpha$-Ylangene & Sesquiterpene & 2.36 \\
\hline 23.180 & 1381 & 1389 & $\beta$-Elemene & Sesquiterpene & 0.62 \\
\hline 24.033 & 1400 & 1409 & $\alpha$-Gurjunene & Sesquiterpene & 0.42 \\
\hline 24.303 & 1407 & 1417 & (E)-Caryophyllene & Sesquiterpene & 10.96 \\
\hline 25.667 & 1440 & 1452 & $\alpha$-Humulene & Sesquiterpene & 0.87 \\
\hline 25.967 & 1447 & 1458 & Allo-aromadendrene & Sesquiterpene & 1.49 \\
\hline 26.617 & 1462 & 1464 & 9-epi-(E)-Caryophyllene & Sesquiterpene & 0.66 \\
\hline 26.747 & 1466 & 1480 & Germacrene D & Sesquiterpene & 1.52 \\
\hline 26.963 & 1471 & 1489 & $\beta$-Selinene & Sesquiterpene & 0.72 \\
\hline 27.417 & 1482 & 1496 & Viridiflorene & Sesquiterpene & 2.50 \\
\hline 27.597 & 1486 & 1500 & $\alpha$-Muurolene & Sesquiterpene & 0.76 \\
\hline 28.240 & 1502 & 1521 & trans-Calamenene & Sesquiterpene & 19.10 \\
\hline 28.480 & 1508 & 1511 & $\delta$-Amorphene & Sesquiterpene & 4.22 \\
\hline 28.943 & 1519 & 1544 & $\alpha$-Calacorene & Sesquiterpene & 0.60 \\
\hline 30.260 & 1552 & 1577 & Spathulenol & Oxygenated sesquiterpene & 5.03 \\
\hline 30.453 & 1557 & 1582 & Caryophyllene oxide & Oxygenated sesquiterpene & 2.54 \\
\hline 30.653 & 1562 & 1590 & Globulol & Oxygenated sesquiterpene & 2.38 \\
\hline 30.927 & 1569 & 1600 & Guaiol & Oxygenated sesquiterpene & 3.18 \\
\hline 31.053 & 1572 & 1595 & Cubeban-11-ol & Oxygenated sesquiterpene & 1.77 \\
\hline 31.383 & 1580 & 1602 & Ledol & Oxygenated sesquiterpene & 2.95 \\
\hline 31.957 & 1595 & 1618 & Junenol & Oxygenated sesquiterpene & 0.79 \\
\hline 32.357 & 1605 & 1627 & 1-epi-Cubenol & Oxygenated sesquiterpene & 1.08 \\
\hline 32.793 & 1616 & 1640 & epi- $\alpha$-Muurolol & Oxygenated sesquiterpene & 3.34 \\
\hline 33.133 & 1625 & 1651 & Pogostol & Oxygenated sesquiterpene & 3.40 \\
\hline 33.230 & 1628 & 1644 & $\alpha$-Muurolol & Oxygenated sesquiterpene & 3.59 \\
\hline \multicolumn{4}{|c|}{ Monoterpene } & & 7.20 \\
\hline \multicolumn{4}{|c|}{ Oxygenated monoterpene } & & 6.00 \\
\hline \multicolumn{4}{|c|}{ Sesquiterpene } & & 47.81 \\
\hline \multicolumn{4}{|c|}{ Oxygenated sesquiterpene } & & 30.05 \\
\hline \multicolumn{3}{|c|}{ Total identified } & & & 91.06 \\
\hline
\end{tabular}

$\mathrm{RT}=$ Retention time (min), $\mathrm{RI}_{\text {cal }}=$ Kovats retention index experimentally calculated, $\mathrm{RI}_{\mathrm{lit}}=$ Kovats retention index (Adams, 2007), $\%=$ Composition. 
$91.06 \%$ of identified components present in the EO). Among the 34 identified compounds, $47.81 \%$ were sesquiterpenes, $30.05 \%$ oxygenated sesquiterpenes, $7.20 \%$ monoterpenes and $6.00 \%$ oxygenated monoterpenes. Sesquiterpenes are prominent in the majority of species from the Myrcia genus (Cerqueira et al., 2009; Rosa et al., 2016, Silva, Uetanabro, Lucchese, 2013).

The major compounds in Myrcia hatschbachii EO were the sesquiterpenes trans-calamenene $(19.10 \%),(\mathrm{E})$ caryophyllene (10.96\%) and spathulenol (5.03\%).

Trans-calamenene was also the main constituent of the species Myrcia obtecta (Stefanello et al., 2010). (E)caryophyllene was previously found in leaves of Myrcia sylvatica (Rosa et al., 2016), Myrcia cuprea (Zoghbi et al., 2003) and Myrcia salzmannii (Cerqueira et al., 2009), and is associated with antibacterial (Huang et al., 2012; Lang, Buchbauer, 2012) and anticarcinogenic activities (Alcântara et al., 2010). The oxygenated sesquiterpene, spathulenol, also has antibacterial (Lang and Buchbauer, 2012) and anticarcinogenic activities (Alcântara et al., 2010), and has been found in the species Myrcia bracteata and Myrcia sylvatica (Zoghbi et al., 2003).

A previous study of composition of EO of fresh leaves from the species Myrcia hatschbachii, collected between the months of November and January, was made for comparison to other species within the same genus. The predominant compounds identified were (E)-caryophyllene $(23.3 \%), \delta$-cadinene $(8.1 \%)$, and bicyclogermacrene (6.9\%) (Limberger et al., 2004). The two latter compounds were not identified in our study.
On the other hand, trans-calamenene (major constituent) has not been reported by Limberger (2004). The variation between the compositions of EO might be related to season and collection site, growth conditions, age of the plant, weather conditions, intensity of the solar radiation, soil composition or genetic variability (Rosa et al., 2016; Sá et al., 2012).

Antioxidant activity as evaluated by the DPPH • radical scavenging method and phosphomolybdenum complex formation assay is summarized in Table II.

Results from the DPPH• radical scavenging method demonstrated that EO was less active than standards. However, due to the fact that this method is more sensitive to polar substances, and that EO has a lipophilic characteristic, composed majoritarily by sesquiterpenes, it was necessary to evaluate antioxidant activity by phosphomolybdenum complex formation assay. EO presented results statistically superior to rutin, which is a flavonoid with known antioxidant properties (Zhang et al., 2016).

The $\mathrm{LC}_{50}$ of EO of Myrcia hatschbachii is summarized in Table III.

According to Meyer et al. (1982), results are considered significant when $\mathrm{LC}_{50}$ is less than $1000 \mu \mathrm{g} /$ $\mathrm{mL}$. According to Amarante et al. (2011), samples where $\mathrm{LC}_{50}$ is between 100 and $500 \mu \mathrm{g} / \mathrm{mL}$, such as the analyzed oil, are considered moderately toxic. In a study performed with the species Myrcia myrtifolia, EO treatment resulted in an $\mathrm{LC}_{50}$ of $479.16 \mu \mathrm{g} / \mathrm{mL}$, suggesting potential usage as antimicrobial (Cerqueira et al., 2007).

TABLE II - Antioxidant activity of Myrcia hatschbachii essential oil

\begin{tabular}{|c|c|c|c|c|c|}
\hline Method & & Essential oil & Ascorbic acid & BHT & Rutin \\
\hline DPPH• scavenging (\%) & & $9.14 \pm 0.33 \%^{\mathrm{a}}$ & $96.66 \pm 0.45 \%{ }^{c}$ & $93.78 \pm 1.08 \%{ }^{b}$ & $94.86 \pm 0.66 \%^{\mathrm{b}}$ \\
\hline \multirow{3}{*}{$\begin{array}{l}\text { Phosphomolybdenum } \\
\text { complex }(\%)\end{array}$} & $\begin{array}{l}\text { Related to Ascorbic } \\
\text { acid }\end{array}$ & $37.32 \pm 1.24 \% \mathrm{o}^{\mathrm{a}}$ & $100^{\mathrm{b}}$ & - & - \\
\hline & Related to BHT & $65.09 \pm 2.17 \% \mathrm{o}^{\mathrm{a}}$ & - & $100^{\mathrm{b}}$ & - \\
\hline & Related to Rutin & $132.46 \pm 4.41 \%{ }^{\mathrm{b}}$ & - & - & $100^{\mathrm{a}}$ \\
\hline
\end{tabular}

BHT $=$ Butylated hydroxytoluene. Results are expressed as average \pm standard deviation. Samples classified in the same group do not differ statistically $(\mathrm{p}<0.05)$, as determined by Tukey's test.

TABLE III - Preliminary in vitro toxicity against Artemia salina

\begin{tabular}{lcccc}
\hline \multirow{2}{*}{ Sample } & LC $_{\mathbf{5 0}} \boldsymbol{\mu g} / \mathbf{m L}$ & \multicolumn{2}{c}{ Chi-square test } \\
\cline { 3 - 5 } & (Confidence Limits) & Chi-square & Degrees of freedom & Significance level \\
\hline Quinidine sulfate & $101.03(59.52-154.92)$ & 14.78 & 5 & 0.01 \\
Essential oil & $409.92(353.36-465.23)$ & 0.63 & 5 & 0.99 \\
\hline
\end{tabular}

$\mathrm{LC}_{50}=$ Concentration able to kill $50 \%$ of brine shrimp. 
To evaluate hemolytic activity, the percentage of hemolysis was calculated against $1 \%$ triton and clean water, which were used as $100 \%$ positive controls. Linear regression was used to determine the concentration necessary to achieve $50 \%$ hemolytic activity. The regression equations were as follows: $\mathrm{y}=0.0334 \mathrm{x}+$ $19.149\left(\mathrm{R}^{2}=0.9902\right)$ for $1 \%$ triton and $\mathrm{y}=0.0321 \mathrm{x}+18.402$ $\left(\mathrm{R}^{2}=0.9902\right)$ for clean water. The abscissa represents the sample concentration and the ordinate is the percentage of hemolysis. The results of this determination were 923.68 $\mu \mathrm{g} / \mathrm{mL}$ for $1 \%$ triton and $984.36 \mu \mathrm{g} / \mathrm{mL}$ for clean water. Hemolysis was dose-dependent.

The biological activities shown using in vitro toxicity tests against Artemia salina and hemolytic activity presented a toxic potential of Myrcia hatschbachii EO and indicate an opportunity of research and evaluation of antitumoral capacity.

EO toxicity might be related to properties of its major constituents. Previous studies have shown that (E)-caryophyllene and spathulenol have anticarcinogenic properties through apoptotic signaling and inhibition of tumor cell proliferation (Alcântara et al., 2010). Moreover, the remaining constituents might act synergistically with the major components, influencing biological activity of the oil.

The toxicity assay against Artemia salina might be used as a model to evaluate acute oral toxicity of plant extracts. In a study using 20 species, toxicity against Artemia salina was compared to toxicity tests made in mice, demonstrating good correlation between the methods in vitro and in vivo (Parra et al., 2001). This experiment is also an indication of potential anticancer activity, and can be used as a pre-screen to investigate activity against solid tumors. The concentration capable of causing lethality of $50 \%$ of the brine shrimp is usually ten times the effective dose of inhibition of the cellular growth in antitumoral tests (McLaughlin, Rogers, Anderson, 1998; Rosa et al., 2016).
In vitro evaluation of hemolytic activity of natural products helps to determine possible damage caused to the membranes of erythrocytes by the constituents of EO. When red blood cells undergo lysis, hemoglobin is released (Sobrinho et al., 2016). Thus, hemolytic activity is considered a preliminary test of toxicity of vegetal samples, especially when evaluating potential therapeutic activities.

Antioxidant activity also showed relevant results for Myrcia hatschbachii EO. Compounds with antioxidant capacity are of interest with regard to treatment and prevention of cancers. An example of these compounds is ascorbic acid. At higher concentrations, ascorbic acid might enhance production of ATP and induce apoptosis in tumor cells through a pro-oxidant mechanism (Mata et al., 2016).

Regarding antibacterial activity, Myrcia hatschbachii EO treatment resulted in a MIC of $500 \mu \mathrm{g} / \mathrm{mL}$ (moderate activity) for Enterococcus faecalis and $1000 \mu \mathrm{g} / \mathrm{mL}$ (weak activity) for Staphylococcus aureus. These bacteria are important pathogens in foodborne illnesses (Jesus et al., 2016). For the remaining microorganisms, EO showed MIC results greater than $1000 \mu \mathrm{g} / \mathrm{mL}$. EO of Myrcia alogenensis (Silva et al., 2013) and Myrcia myrtifolia (Cerqueira et al., 2007) exhibited activity against Staphylococcus aureus. In contrast, EO from Myrcia fallax (Alarcón et al., 2009) and Myrcia splendens (Jiménez et al., 2012) were active against Staphylococcus aureus and Enterococcus faecalis.

Phytotoxic activity was evaluated by examining the influence of EO of Myrcia hatschbachii on germination and growth of Lactuca sativa seeds. Regarding the germination results, no statistical differences were observed compared to water and $1 \%$ polysorbate controls. However, at the concentration of $1 \%$, EO negatively affected germination speed index (GSI). Results are summarized in Table IV.

TABLE IV - Influence of essential oil of Myrcia hatschbachii on GSI and growth of hypocotyls and radicles of Lactuca sativa

\begin{tabular}{|c|c|c|c|c|c|c|c|}
\hline \multirow{2}{*}{$\begin{array}{l}\text { Control/ } \\
\text { Sample }\end{array}$} & \multirow{2}{*}{$\begin{array}{c}\text { Concentration } \\
(\% \mathrm{~m} / \mathrm{v})\end{array}$} & \multicolumn{2}{|c|}{ GSI } & \multicolumn{2}{|c|}{ Hypocotyl } & \multicolumn{2}{|c|}{ Radicle } \\
\hline & & Average & Scott-Knott & Average (mm) & Scott-Knott & Average (mm) & Scott-Knott \\
\hline Water & - & 4.88 & $\mathrm{~b}$ & 33.10 & $\mathrm{c}$ & 37.65 & $\mathrm{c}$ \\
\hline Polysorbate & - & 4.63 & $\mathrm{~b}$ & 30.20 & $\mathrm{c}$ & 34.60 & $\mathrm{c}$ \\
\hline \multirow{4}{*}{ Essential oil } & 0.001 & 5.00 & $\mathrm{~b}$ & 26.60 & $\mathrm{~b}$ & 30.00 & $\mathrm{~b}$ \\
\hline & 0.01 & 4.52 & $\mathrm{~b}$ & 26.75 & $\mathrm{~b}$ & 27.80 & $\mathrm{~b}$ \\
\hline & 0.1 & 4.46 & $\mathrm{~b}$ & 24.85 & $\mathrm{~b}$ & 35.20 & $\mathrm{c}$ \\
\hline & 1 & 3.33 & $\mathrm{a}$ & 4.95 & $\mathrm{a}$ & 15.35 & $\mathrm{a}$ \\
\hline
\end{tabular}

GSI = Germination Speed Index. Samples classified in the same group do not differ significantly $(p<0.05)$, as determined by the Scott Knott test. 
Growth results of both hypocotyl and radicle, showed the most expressive activity in $1 \%$ preparations. All concentrations of EO tested inhibited growth of the hypocotyl of Lactuca sativa. Regarding the radicle, the oil presented more significant results growth inhibition results at the concentration of $1 \%$, but the concentrations $0.001 \%$ and $0.01 \%$ also presented negative influence according to the statistical analysis, compared to the controls water and polysorbate at $1 \%$ in water.

A previous study examining Myrcia guianensis EO showed greater potential as an inhibitor of seed germination than radicle or hypocotyl growth in seeds of Mimosa pudica and Senna obtusifolia (Souza Filho et al., 2006).

Our results showing inhibition of growth of the hypocotyl and radicle of Lactuca sativa demonstrate the phytotoxic potential of Myrcia hatschbachii and support further investigation of this species for development and production of natural herbicides.

Study of metabolites as allelochemicals has increased recently, focused mainly on production of bioherbicides. These agents might be used as alternatives for synthetic agrochemicals, which are associated with health risks and negative environmental impact. Thus, the search for bioherbicides becomes an alternative for sustainable agriculture with the utilization of medicinal plants at the farming of foods free of agrochemicals. It also contributes to the reduction of costs at the production chain, as they tend to be cheaper than the traditional herbicides (Santiago et al., 2017).

A general assay to predict possible therapeutic or biological activity of plant species would aid in research and development of new products and new drugs (Rosa et al., 2016).

This study demonstrates that EO of Myrcia hatschbachii could be used in agriculture for development of bioherbicides based on phytotoxic potential. In vitro toxicity tests point to the execution of antitumoral activity tests, searching for prospection of antineoplastic drugs. Finally, these EO also exhibit antibacterial activity against two important foodborne bacteria: Staphylococcus aureus and Enterococcus faecalis.

\section{ACKNOWLEDGMENTS}

This work was supported by the Coordenação de Aperfeiçoamento de Pessoal de Nível Superior (CAPES). The authors are grateful to the Department of Chemistry of the Federal University of Parana, Brazil, for the help in GC / MS analysis.

\section{REFERENCES}

Adams, RP. Identification of essential oil components by gas chromatography / mass spectrometry. 4 ed. Carol Stream IL: Allured Publishing; 2007. 804 p.

Alarcón LD, Peña AE, Gonzales CN, Quintero A, Meza M, Usubillaga A, et al. Composition and antibacterial activity of the essential oil of Myrcia fallax (Rich.) DC. from Venezuela. Rev Soc Quím Perú. 2009;75(2):221-227.

Alcântara JM, Yamaguchi KK de L, Veiga Junior VF da, Lima ES. Composição química dos óleos essenciais de espécies de Aniba e Licaria e suas atividades antioxidantes e antiagregante plaquetária. Quím Nova. 2010;33(1):141-145.

Amarante CB, Müller AH, Póvoa MM, Dolabela MF. Estudo fitoquímico biomonitorado pelos ensaios de toxicidade frente à Artemia salina e de atividade antiplasmódica do caule de aninga (Montrichardia linifera). Acta Amaz. 2011;41(3):431-434.

Ayres MCC, Brandão MS, Vieira-Júnior GM, Menor JCAS, Silva HB, Soares MJS, et al. Atividade antibacteriana de plantas úteis e constituintes químicos da raiz de Copernicia prunifera. Rev Bras Farmacogn. 2008;18(1):90-97.

Banerjee A, Kunwar A, Mishra B, Priyadarsini KI. Concentration dependent antioxidant/pro-oxidant activity of curcumin: Studies from AAPH induced hemolysis of RBCs. Chem Biol Interact. 2008;174(2):134-139.

Barreiro EJ, Bolzani VDS. Biodiversidade: fonte potencial para a descoberta de farmacos. Quím Nova. 2009;32(3):679-688.

Cascaes MM, Guilhon GM, Andrade EH, Zoghbi MD, Santos L da S. Constituents and Pharmacological Activities of Myrcia (Myrtaceae): A Review of an Aromatic and Medicinal Group of Plants. Int J Mol Sci. 2015;16(10):23881-904.

Cerqueira MD, Souza-Neta LC, Passos MGVM, Lima EO, Roque NF, Martins D, et al. Seasonal Variation and Antimicrobial Activity of Myrcia myrtifolia essential oils. J Braz Chem Soc. 2007;18(5):998-1003.

Cerqueira MD, Marques EJ, Martins D, Roque NF, Cruz FG, Guedes MLS. Variação sazonal da composição do essential oil de Myrcia salzmannii Berg. (Myrtaceae). Quím Nova. 2009;32(6):1544-1548. 
Clinical and Laboratory Standard Institute. CLSI. Methods for dilution antimicrobial susceptibility tests for bacteria that grow aerobically. M07-A8; 2008.

Huang M, Sanchez-Moreiras AM, Abel C, Sohrabi R, Lee S, Gershenzon J, et al. The major volatile organic compound emitted from Arabidopsis thaliana, the sesquiterpene $\beta$-caryophyllene, is a defense against a bacterial pathogen. New Phytol. 2012;193(4):997-1008.

Jesus IC de, Frazão GGS, Blank AF, Santana LC de A. Myrcia ovata Cambessedes essential oils: A proposal for a novel natural antimicrobial against foodborne bacteria. Microb Pathog. 2016;99:142-147.

Jiménez D, Araque M, Rojas L, Cordero A, Briceño B. Componentes volátiles y actividad antibacteriana del vástago de Myrcia splendens (Sw.) DC. Rev Fac Farm. 2012;54:7-11.

Lang $\mathrm{G}$, Buchbauer $\mathrm{G}$. A review on recent research results (2008-2010) on essential oils as antimicrobials and antifungals. A review. Flavour Fragr J. 2012;27(1):13-39.

Lima MAA, Oliveira FFM, Gomes GA, Lavor PL, Santiago GMP, Nagao-Dias AT, et al. Evaluation of larvicidal activity of the essential oils of plants from Brazil against Aedes aegypti (Diptera: Culicidae). Afr J Biotechnol. 2011;10(55):11716-20.

Limberger RP, Sobral M, Henriques AT, Menut C, Bessiere JM. Óleos voláteis de espécies de Myrcia nativas do Rio Grande do Sul. Quím Nova. 2004;27(6):916-919.

Mata AMOF da, Carvalho RM, Alencar MVOB, Cavalcante AACM, Silva BB. Ascorbic acid in the prevention and treatment of cancer. Rev Assoc Med Bras. 2016;62(7):680-686.

Mclaughlin JL, Rogers LL, Anderson JE. The use of biological assays to evaluate botanicals. Drug Inf J. 1998;32:513-524.

Mensor LL, Menezes FS, Leitão GG, Reis AS, Santos TCD, Coube CS, Leitão SG. Screening of Brazilian plant extracts for antioxidant activity by the use of DPPH free radical method. Phytother Res. 2001;15(2):127-130.

Meyer BN, Ferrigni NR, Putnam JE, Jacobsen LB, Nichols DJ, McLaughlin JL. Brine shrimp: a convenient general bioassay for active plant constituents. Planta Med. 1982;45(5):31-34.

Moresco HH, Pereira M, Bretanha LC, Micke GA, Pizzolatti MG, Brighente IMC. Myricitrin as the main constituent of two species of Myrcia. J Appl Pharm Sci. 2014;4(2):1-7.
Parra AL, Yhebra RS, Sardiñas IG, Buela LI. Comparative study of the assay of Artemia salina L. and the estimate of the medium lethal dose (LD50 value) in mice, to determine oral acute toxicicty of plant extracts. Phytomedicine. 2001;8(5):395-400.

Prieto P, Pineda M, Aguilar M. Spectrophotometric quantitation of antioxidant capacity through the formation of a phosphomolybdenum complex: specific application to the determination of vitamin E. Anal Biochem. 1999;269(2):337341 .

Retamales HA, Scharaschkin T. Comparative leaf anatomy and micromorphology of the Chilean Myrtaceae: Taxonomic and ecological implications. Flora. 2015;217:138-154.

Rosa CS, Veras KS, Silva PR, Lopes Neto JJ, Cardoso HLM, Alves LPL, et al. Composição química e toxicidade frente Aedes aegypti L. e Artemia salina Leach do óleo essencial das folhas de Myrcia sylvatica (G. Mey.) DC. Rev Bras P1 Med. 2016;18(1):19-26.

Sá FAS, Borges LL, Paula JAM, Sampaio BL, Ferri PH, Paula JR. Essential oil in aerial parts of Myrcia tomentosa composition and variability. Rev Bras Farmacogn. 2012;22(6):1233-1240.

Santiago JA, Cardoso MG, Cruz FA, Palmieri MJ, Souza RV, Soares LI, et al. Cytogenotoxic effect of essential oil from Backhousia citriodora L. (Myrtaceae) on meristematic cells of Lactuca sativa L. South Afr J Bot. 2017;112:515-520.

Santos AO dos, Nakamura TU, Dias Filho BP, Veiga Junior VF, Pinto AC, Nakamura CV. Antimicrobial activity of Brazilian copaiba oils obtained from different species of the Copaifera genus. Mem Inst Oswaldo Cruz. 2008;103(3):277-281.

Santos GCM, Gomes GA, Gonçalves GM, Sousa LM, Santiago GMP, Carvalho MG, et al. Essential oil from Myrcia ovata: Chemical composition, antinociceptive and anti-inflammatory properties in mice. Planta Med. 2014;80(17):1588-1596.

Silva AN, Uetanabaro APT, Lucchese AM. Chemical Composition and Antibacterial Activity of Essential Oils from Myrcia alagoensis (Myrtaceae). Nat Prod Commun. 2013;8(2):269-271.

Silva ER, Overbeck GE, Soares GLG. Phytotoxicity of volatiles from fresh and dry leaves of two Asteraceae shrubs: evaluation of seasonal effects. South Afr J Bot. 2014;93:14-18. 
Sobral M, Proença C, Souza M, Mazine F, Lucas E. Myrtaceae in Lista de Espécies da Flora do Brasil. Jardim Botânico do Rio de Janeiro, 2015. [citad 2018 Feb 02]. Available from: http:// floradobrasil.jbrj.gov.br/jabot/floradobrasil/FB1070.

Sobrinho ACN, Souza EB, Rocha MFG, Albuquerque MRJR, Bandeira PN, Santos HS, et al. Chemical composition, antioxidant, antifungal and hemolytic activities of essential oil from Baccharis trinervis (Lam.) Pers. (Asteraceae). Ind Crops Prod. 2016;84:108-115.

Souza Filho APS, Santos RA, Santos LS, Guilhon GMP, Santos AS, Arruda MSP, et al. Allelophatic Potential of Myrcia guianensis. Planta Daninha. 2006;24(4):649-656.

Stefanello MEA, Cervi AC, Wisniewski Junior A, Simionatto EL. Composição e variação sazonal do óleo essencial de Myrcia obtecta (O.Berg) Kiaersk. var. obtecta, Myrtaceae. Rev Bras Farmacogn. 2010;20(1):82-86.
Stefanello MEA, Riva D, Simionatto EL, Carvalho JE, Ruiz ALTG, Salvador MJ. Chemical composition and cytotoxic activity of essential oil from Myrcia laruotteana fruits. J Essent Oil Res. 2011;23(5):7-10.

Takao LK, Imatomi L, Gualtieri SCJ. Antioxidant activity and phenolic content of leaf infusions of Myrtaceae species from Cerrado (Brazilian Savanna). Braz J Biol. 2015;75(4):948-952.

Zhang R, Zhang BL, He T, Yi T, Yang JP, He B. Increase of rutin antioxidant activity by generating Maillard reaction products with lysine. Bioorganic Med Chem Lett. 2016;26(11):26802684.

Zoghbi MGB, Andrade EHA, Silva MHL, Carreira LMM, Maia JGS. Essential oils from three Myrcia species. Flavour Fragr J. 2003;18(5fig):421-424.

Received for publication on $29^{\text {th }}$ May 2018 Accepted for publication on $25^{\text {th }}$ September 2018 